\title{
PROBLEM RECEPCJI NA ZACHODZIE NAUKI O OBRAZACH SOBORU NICEJSKIEGO II
}

Dziś, 1230 lat od zakończenia Niceanum II, ostatniego soboru ekumenicznego uznawanego zarówno przez Kościół Wschodni, jak i Zachodni, na którym sformułowano naukę dotyczącą kultu obrazów, warto na nowo przyjrzeć się jego orzeczeniom i ich recepcji na Zachodzie. Spuścizna ta jest bowiem aktualna szczególnie w XXI wieku, kiedy żyjemy w świecie zdominowanym przez obraz i komunikację wizualną, których wykorzystanie w ewangelizacji wydaje się być wymogiem naszych czasów. Dlatego też, by po raz wtóry odkryć prawdziwą wartość tej nauki, potrzebna jest pogłębiona refleksja teologiczna nad miejscem i rolą świętego obrazu w Kościele, w którym kult obrazów został ograniczony jedynie do tych uznanych za cudowne. Tym bardziej, że w niektórych kręgach wciąż żywa jest pokusa obrazoburcza, czyli niechęć do przekazywania prawd wiary poprzez obrazy religijne, ikony ${ }^{1}$, a także „nie brakuje nadużyć związanych z obrazami, wśród których są obecne zarówno te o charakterze bluźnierczym czy nawet satanistycznym, jak i te o charakterze bałwochwalczym"”.

Ponadto „stare pojęcie ikonologii nadal oczekuje na wypełnienie sensem odpowiadającym naszej współczesności”3. Co więcej, „w odróżnieniu od teologii budowanej przy pomocy słowa, teologia obrazu wciąż domaga się precyzowania jej metodologii’"4, szczególnie biorąc pod uwagę „zawarty w obrazie potencjał perswazyjny"s k kóry można wykorzystać w głoszeniu Dobrej Nowiny zwłaszcza wśród ludzi młodych, czyniąc - poprzez obraz - zrozumiałe to, co się słyszy, a czego się jeszcze nie rozumie.

\footnotetext{
* Mgr DARIUSz CheŁSTOWSKI - specjalista z zakresu teorii kultury, redaktor naczelny kwartalnika Prawo Nowych Mediów; E-mail:dchelstowski@o2.pl

${ }^{1}$ Zob. Ch. Schönborn, Pokusa obrazoburcza, Communio 2/1990, s. 60-71.

2 J. Królikowski, Chrystologia i obraz w Kościele, w: Tenże, Nieme stowo. Teologia w sztuce, Tarnów 2008, s. 81.

${ }^{3}$ H. Belting, Antropologia obrazu. Szkice do nauki o obrazie, tł. M. Bryl, Kraków 2007, s. 18.

${ }^{4}$ K. Klauza, Teologiczna hermeneutyka ikony, Lublin 2002, s. 10.

${ }_{5}^{5}$ Z. Treppa, Tajemnica widzialności Boga. Szkice z teologii obrazu, Kraków 2015, s. 11.
} 


\section{AFIRMACJA KATECHETYCZNEJ I KULTOWEJ ROLI SZTUKI RELIGIJNEJ}

Siódmy Sobór Ekumeniczny był niezbędny dla rozstrzygnięcia ostatniej wielkiej walki dogmatycznej na Wschodzie, związanej z czcią i obrazów. Na szóstej sesji, która odbyła się 6 października 787 roku, po wysłuchaniu wielu wyjątków z Pisma Świętego i dzieł Ojców Kościoła, które przemawiały za kultem obrazów, odczytano i poddano szczegółowej krytyce postanowienia synodu ikonoklastycznego w Hiereia z 754 roku.

Sobór jednoznacznie potępił ikonoklazm jako herezję, która wzięła swoje korzenie od wyznawców religii Mojżesza i Mahometa, a także zwolenników doktryny Manicheusza ${ }^{6}$, nakazał zniszczenie całej literatury ikonoklastycznej i przywrócenie kultu obrazów. Opierając się na nauce Jana z Damaszku, wprowadzono rozróżnienie między uwielbieniem (latreía), odnoszącym się tylko do samego Boga, a szacunkiem (proskýnesis), który może być oddawany obrazom Chrystusa i świętych, ponieważ dotyczy przedstawionych na nich osób. Z kolei chrystologię ikonoklastyczną ogłoszono za błędną, gdyż nie akceptowała Wcielenia Chrystusa. Twierdzenie, że kult obrazów jest pozbawiony jakiejkolwiek wartości było, według soboru, wprowadzaniem nestoriańskiego rozróżnienia między tym, co ludzkie a tym, co Boskie. Utrzymywanie zaś, że oddawanie czci obrazom jest bałwochwalstwem zostało uznane za monofizytyzm. Ponadto nakazano, aby każdego, kto niszczy obrazy albo przeszkadza ich kultowi, obłożyć ekskomuniką.

Teologia przyjęta na Soborze Nicejskim II stanowiła kontynuację chrystologii poprzednich soborów, szczególnie jeśli chodzi o fakt Wcielenia. Obraz był więc pośrednikiem pomiędzy widzialnym a niewidzialnym, między wyobrażeniem a pierwowzorem, do którego prowadzi

Sobór uznał, iż Pismo Święte i obraz religijny „ukazują i wyjaśniają” się wzajemnie. Odsłaniają jedną i tę samą prawdę wyrażoną w dwóch różnych formach: słownej i obrazowej. Dlatego też odtąd obraz w oczach Kościoła nie jest sztuką czy ilustracją Pisma Świętego, ale językiem, za pośrednictwem którego dokonuje się pouczenie w wierze ${ }^{8}$. Warto jednak zwrócić uwagę, że ojcowie soborowi, nie zajmując się wszystkimi spornymi kwestiami, m.in. świętością ikony i łaskami, które ona ze sobą niesie - tak wyraźnie wyeksponowanymi u św. Jana z Damaszku - wykazali się „roztropną ostrożnością”. Niektóre zagadnienia wymagały dopiero czasu na ostateczne rozstrzygnięcie w IX wieku przez Teodora Studytę i Nicefora, którzy rozwinęli i doprecyzowali nicejską teologię ikony9.

${ }^{6}$ Sz. Włodarski, Siedem soborów ekumenicznych, Warszawa 1969, s. 202.

${ }^{7}$ M. Starowieyski, Sobory Kościoła Niepodzielonego, część 1 - Dzieje, Tarnów 1994, s. 124.

8 Tamże.

${ }^{9}$ M. Pyc, Misterium Chrystusa w centrum debaty nad ikonami na Soborze Nicejskim II, w: Wokót teologii ikony, red. B. Kochaniewicz, Studia Theologiae Fundamentalis, tom 2, Poznań 2011, s. 104n. 
Uroczyste zamknięcie obrad w Konstantynopolu nastąpiło 28 października 787 roku. Dokumenty soborowe podpisali wszyscy jego uczestnicy: zarówno biskupi bizantyjscy, jak i przedstawiciele Rzymu czy innych Kościołów Wschodnich. Jednakże papiestwo nigdy nie aprobowało kanonów nicejskich wskutek odrzucenia ich przez dwór karoliński. Co więcej, całkowite zignorowanie nauki Soboru Nicejskiego II dotyczącej kultu obrazów doprowadziło do powstania zachodniego ikonoklazmu, popieranego przez Karola Wielkiego.

\section{KOŚCIÓŁ KATOLICKI O ŚWIĘTYCH OBRAZACH}

Opracowanie przez Jana Damasceńskiego, Teodora Studytę i Nicefora ortodoksyjnej nauki dotyczącej kultu obrazów, a także przyjęcie stosownych postanowień przez VII Sobór Ekumeniczny w Nicei, miało całkowicie rozstrzygnąć tę sprawę i ostatecznie rozwiązać toczący się od dwóch stuleci spór. Wtedy ikonoklazm uważano za zamknięty już, niechlubny rozdział w historii Kościoła. Jednak problematyka kultu obrazów pojawiła się ponownie jeszcze w VIII wieku w Libri Carolini - które były odpowiedzią Zachodu, a dokładnie cesarza Karola Wielkiego, na orzeczenia Niceanum II - a następnie na soborze (synodzie) w Konstantynopolu ${ }^{10}$ (869/870). Potwierdził on wprawdzie naukę II Soboru Nicejskiego, który uznał równość Pisma Świętego i świętych wizerunków w funkcjach liturgicznych, ale było to tylko na marginesie innych kwestii ${ }^{11}$. Ta pełna rezerwy postawa wobec kultu obrazów w Kościele Zachodnim niestety pozostała.

Następnie idee ikonoklastyczne ujrzały światło dzienne kilka stuleci później w hasłach Reformacji. W XVI wieku w doktrynie reformatorów pojawiły się wątki obrazoburcze, a tym samym nastąpiło odnowienie idei ikonoklastycznych ${ }^{12}$.

${ }^{10}$ Kościół Katolicki uważa go za Sobór Konstantynopolitański IV, chociaż na sesji otwierającej pojawiło się jedynie 12 biskupów. Zob. M. Starowieyski, Sobory Kościoła Niepodzielonego, dz. cyt., s. 140.

11 Jeden z przyjętych wówczas kanonów (kanon 3.) stanowił: „Wizerunek Pana naszego Jezusa Chrystusa powinien być otaczany czcią i adoracją tak samo jak księgi świętych ewangelii i figura drogocennego krzyża; podobnie niech będą czczone obrazy Niepokalanej Matki Jego, Bożej Rodzicielki Marii oraz wszystkich świętych i aniołów /.../. Kto zajmuje w tej sprawie inne stanowisko niech będzie odłączony od Ojca i Syna i Ducha Świętego". Dokumenty Soborów Powszechnych, t. 2, oprac. A. Baron, H. Pietras, Kraków 2003, s. 55-57.

12 W XV i XVI wieku na terenach Rusi można zaobserwować lokalny wzrost zainteresowania doktryną ikonoklastyczną, szczególnie wśród ruchów heretyckich, np. strzygolników, a przede wszystkim judaizantów. „Ikony traktowano jako święte, a wystąpienia przeciw nim - jako świętokradztwo, które przez kodeks Iwana III z roku 1497, pierwsze prawo obowiązujące w państwie moskiewskim, uznawane było za jedno z najcięższych przewinień”. Zob. A. Sulikowska-Gąska, Spory o ikony na Rusi w XV i XVI w. Warszawa 2007, s. 37. Jednak co do intencji tego obrazoburstwa nie ma zgody: 
W kwestii obrazów religijnych wypowiedziały się również sobory Kościoła Zachodniego: Trydencki i Watykański II.

\section{LIBRI CAROLINI JAKO ODPOWIEDŹ ZACHODU NA POSTANOWIENIA NICEANUM II}

Po Soborze Nicejskim II Karol Wielki otrzymał łaciński przekład dokumentów soborowych. Niestety błędy językowe występujące w tym tekście zniekształciły właściwy sens powziętych w Nicei uchwa $1^{13}$. W odpowiedzi na nie cesarz przedstawił swój punk widzenia na ten temat w tzw. Libri Carolini ${ }^{14}$, autorstwa Teodulfa z Orleanu ${ }^{15}$. Karol niechętny Grekom z przyczyn politycznych, chodziło bowiem o niezależność religijną od Bizancjum, odrzucił zarówno ikonoklastyczny, jak i ikonofilski punkt widzenia. Co więcej, na Zachodzie zupełnie nie rozumiano teologii obrazu; obraz stanowił tam tylko ozdobę ścian ${ }^{16}$. Dlatego też, według koncepcji

z jednej strony wymienia się zwykły wandalizm, będący następstwem pijaństwa, z drugiej zaś nie docenia się świadomego ikonoklazmu. Należy również dodać, że pojawienie się na tym terenie przedstawień niekanonicznych często nie miało nic wspólnego z wpływami ruchów heretyckich, tylko było wynikiem oddziaływania sztuki zachodniej. Na temat dyskusji o kulcie obrazów na Rusi w tym okresie zob. też B. Dąb-Kalinowska, Ruska teologia ikony w polemice z heretykami, w: B. Dąb-Kalinowska, Ikony i obrazy, Warszawa 2000, s. 92-100.

${ }_{13}$ Zasadnicze znaczenia ma tu przede wszystkim przetłumaczenie greckich słów proskýnesis (szacunek np. dla świętych obrazów) i latreía (uwielbienie Boga) jednym określeniem adoratio (adoracja, która dla w Kościele Zachodnim była przynależna tylko Bogu). Atanazy Bibliotekarz kilkadziesiąt lat później przypisał to fatalne tłumaczenie anonimowemu autorowi, który w ogóle nie znał ani łaciny, ani greki. Zob. M. Chudzikowska-Wołoszyn, Księgi karolińskie - frankońska odpowiedź na Sobór Nicejski II z roku 787, Studia Warmińskie XLIV-XLV (2007-2008), s. 36, 37n.

${ }^{14}$ Szczegółowe informacje na ten temat zawiera artykuł S. Gero, The Libri Carolini and the image controversy, The Greek Orthodox Theological Review (1973) nr 1-2, s. 7-34. Zob. też M. Pokorska, ,Cibus oculorum”. Uwagi o teorii dzieła sztuki w „Libri Carolini”, Folia Historiae Artium, T. XXVII (1991), s. 13-31.

${ }_{15}$ Przez wiele lat za autora Libri Carolini uważano Alkuina, m.in. ze względu na zawarte tam, typowe dla niego, tezy i sformułowania. Jednak ostatecznie autorstwo tego dzieła przypisano Teodulfowi z Orleanu. Trzeba też zaznaczyć, że w opracowywaniu tekstu osobiście brał udział Karol Wielki, o czym świadczą dopiski na watykańskim oryginale Libri Carolini. Zob. D. A. Sikorski, Alkuin z Yorku na nowo odkrywany, w: Cognitioni Gestorum. Studia z dziejów średniowiecza dedykowane prof. Jerzemu Strzelczykowi, red. D. A. Sikorski, A. M. Wyrwa, Poznań-Warszawa 2006, s. 102, 113.

${ }^{16}$ „Zwykle obrazy powstają zgodnie ze zdolnościami artystów. Niektóre są zatem plastyczne i proporcjonalne, inne zaś bez wyrazu, czasami mogą być piękne, nieraz również i brzydkie, jedne z nich są bardziej podobne do pierwowzoru, inne natomiast przeciwnie - w ogóle go nie przypominają, niektóre błyszczą nowością, a inne znów pękają ze starości. Można zatem zapytać, które z nich będą bardziej czczone, czy te, które mają większą wartość, czy może te, o których wiemy, że są bezwartościowe? Jeśli oddajemy większą cześć tym cenniejszym [obrazom], to w tym przy- 
obrazu przedstawionej w Libri Carolini, Bóg nie mógł objawiać się w przedmiotach materialnych, gdyż jest On niewidzialny i bezcielesny, zaś cześć można $\mathrm{Mu}$ oddawać jedynie w duchu i prawdzie, a nie w malowanych farbami obrazach, które są tworzone tylko po to, by upamiętnić jakieś wydarzenie historyczne lub być ozdobą kościołów ${ }^{17}$. Ponadto w doktrynie karolińskiej nie było różnicy między sztuką religijną a świecką, a nawet pogańską. Tym, co odróżniało od siebie dane obrazy był kunszt artystyczny i jakość wykorzystanych materiałów.

Natomiast o tym, jaka jest właściwa treść danego dzieła sztuki decydował komentarz słowny, umieszczony na obrazie, np. ten sam portret młodej kobiety mógł być podpisany jako „Matka Boża” lub „Wenus” ${ }^{18}$. Według karolińskiej teorii obrazu oglądający dzieło jest bardziej koneserem sztuki, zachwycającym się jego wartością artystyczną niż wiernym kontemplującym dane przedstawienie o treści religijnej.

Trzeba też podkreślić, że Libri Carolini nigdzie nie wzywały do niszczenia dzieł sztuki, wręcz przeciwnie. „Pozwalamy tworzyć święte obrazy każdemu, kto tylko zechce, /.../ do oddawania im czci nie zmuszamy tych, o których wiemy, że

padku czcimy tylko same dzieło czy materiały, z których jest wykonane, zaś nie czynimy tego z żarliwej wiary. Jeśli natomiast te o mniejszej wartości i mniej podobne do [pierwowzoru], to jest to niesprawiedliwe, że czcimy je bardziej i gorliwiej niż te pierwsze, i to nie z powodu jakości samego dzieła, znakomitych materiałów czy dokładnego oddania podobieństwa. Zaiste w obrazach niczego nie odrzucamy z wyjątkiem oddawania im czci [bałwochwalczej], zwłaszcza, że pozwalamy mieć w bazylikach obrazy świętych, ale nie po to, by oddawać im cześć, lecz, by przypominały o rzeczach minionych i ozdabiały ściany". Teodulf z Orleanu, Opus Caroli regis contra synodum (Libri Carolini), wyd. A. Freeman, Hannover 1998, III, 16, s. 410-411. Por. Libri Carolini (Contra synodum quae in partibus Graeciae pro adorandis imaginibus stolide sive arroganter gesta est), III, 16 (PL 98, 1147 CD).

17 „O wielbicielu obrazów, o czcicielu rzeczy bezsensownych, które możesz [wokół siebie] znaleźć. /.../ Ty przyglądaj się świecącym malowidłom, my będziemy zgłębiać Święte Pisma! Bądź czcicielem sztucznych kolorów, my zaś będziemy czcicielami tego, co wymyka się zmysłom! Głaszcz sobie malowane deski, my natomiast będziemy z radością zachwycać się sprawami Bożymi!". Teodulf z Orleanu, Opus Caroli regis contra synodum (Libri Carolini), wyd. A. Freeman, Hannover 1998, II, 30, s. 317. Por. Libri Carolini (Contra synodum quae in partibus Graeciae pro adorandis imaginibus stolide sive arroganter gesta est), II, 30 (PL 98, 1106 CD).

18 „Dla przykładu, komuś z tych, którzy oddają cześć obrazom pokazano dwa obrazy pięknych kobiet, na których nie było podpisu i które ktoś mało uważny porzucił w jakimś miejscu. Powiedziano mu: ,Jednym z nich jest obraz Najświętszej Marii Panny, który nie powinien być rzucany gdziekolwiek, drugi zaś jest obrazem Wenus, który może być w ogóle wyrzucony'. Zwraca się on zatem do malarza z pytaniem, który z nich jest obrazem Najświętszej Marii Panny, a który przedstawia Wenus, ponieważ oba są do siebie podobne w każdym szczególe. Ten zaś jeden obraz opatruje podpisem ,Najświętsza Maria Panna', drugi natomiast ,Wenus'. Ten wizerunek, który ma podpis ,Boża Rodzicielka', jest uroczyście obnoszony, oglądany i oddaje się mu cześć, a ten podpisany ,Wenus, matka Eneasza, który uciekł [z Troi]' jest odrzucany i przeklinany. Chociaż oba mają taki sam kształt, takie same kolory i są wykonane z jednakowego materiału, a różnią się jedynie podpisem”. Teodulf z Orleanu, Opus Caroli regis contra synodum (Libri Carolini), wyd. A. Freeman, Hannover 1998, IV, 16, s. 528-529. Por. Libri Carolini (Contra synodum quae in partibus Graeciae pro adorandis imaginibus stolide sive arroganter gesta est), IV, 16 (PL 98, 1219 B). 
tego czynić nie chcą; nie pozwalamy natomiast na ich łamanie i niszczenie, nawet tym, którzy chcieliby to uczynić"19.

Ponieważ, według Karola, Sobór Nicejski nie był prawdziwym soborem ekumenicznym, postanowił on w 794 roku zwołać własny sobór do Frankfurtu. Tam, w obecności dwóch legatów papieskich, potępiono kult obrazów, chociaż w Nicei w 787 roku, w obecności dwóch innych przedstawicieli tego samego papieża, uznano go za obowiązek każdego chrześcijanina ${ }^{20}$. Jednak ostatecznie papież Hadrian I opowiedział się za utrzymaniem kultu obrazów. „Nie w rzeczach widzialnych, nie w ręką ludzką wykonanych przedmiotach, lecz w sercu należy szukać Boga; i nie cielesnymi oczyma, ale jedynie okiem umysłu oglądać się Go winno"21.

Doktryna dotycząca koncepcji i kultu obrazów zawarta w Libri Carolini nawiązywała wprost do poglądów Grzegorza Wielkiego, który swój wykład na ten temat zawarł w listach pasterskich skierowanych do Serenusa, biskupa Marsylii. Pisał w nich m.in., że „obraz jest w tym celu wystawiany w kościele, aby ci, co nie umieją czytać, przynajmniej patrząc na ściany czytali w nich to, czego nie mogą czytać w książkach. /.../ Niszczyć się ich [obrazów] tedy nie godzi [mówi dalej], gdyż zostały umieszczone w kościołach nie dla adoracji, ale jedynie gwoli pouczenia umysłów niewykształconych"22.

Na podstawie nauki zawartej w Libri Carolini należy na koniec stwierdzić, że teologowie karolińscy nie tylko nie znali rzeczywistych (nie zniekształconych przez błędne tłumaczenie akt soborowych) poglądów obrońców obrazów i wypracowanej na soborze teologii świętych wizerunków, ale również całej spuścizny greckich Ojców Kościoła, która była tak istotna przy uzasadnianiu prawomocności kultu obrazów ${ }^{23}$. Zatem nikogo chyba nie powinno dziwić takie, a nie inne podejście Karola Wielkiego i jego teologów do miejsca i roli obrazów w Kościele.

Jak słusznie zauważyła Zofia Bator, to właśnie Libri Carolini, w których odrzucono naukę Soboru Nicejskiego II, miały znaczący wpływ na obecne miejsce i rolę sztuki sakralnej na Zachodzie. Podobne stanowisko wyrażono następnie na kolejnych synodach Kościoła Zachodniego: we Frankfurcie (789 r., 794 r.),

${ }^{19}$ Libri Carolini (Contra synodum quae in partibus Graeciae pro adorandis imaginibus stolide sive arroganter gesta est), IV, 29 (PL 98, 1248 A). W Opus Caroli regis contra synodum (Libri Carolini) (wyd. A. Freeman) powyższy fragment nie występuje.

${ }^{20}$ „Na nowym synodzie Greków w Konstantynopolu podniesiono dwuznaczną kwestię oddawania czci obrazom, o czym zostało [oficjalnie] napisane, że tych, którzy nie stają przed obrazami świętych w pokorze i nie oddają im czci, jak to się zwykło czynić w przypadku Trójcy Świętej, należy obłożyć anatemą. Nasi święci ojcowie już wcześniej i przy każdej sposobności sprzeciwiali się i pogardzali oddawaniem czci obrazom i korzeniem się przed nimi, a tych, którzy to czynią uważają za winnych [bałwochwalstwa]". Kanon II synodu we Frankfurcie w 794 r. (J. D. Mansi, Sacrorum conciliorum nova et amplissima collectio, t. 13, Florentiae 1767, 909 D).

${ }^{21}$ M. Pokorska, ,Cibus oculorum”. Uwagi o teorii dzieła sztuki w „Libri Carolini”, dz. cyt., s. 17.

${ }^{22}$ Tamże, s. 19n.

${ }^{23}$ M. Chudzikowska-Wołoszyn, Księgi karolińskie - frankońska odpowiedź na Sobór Nicejski II z roku 787, dz. cyt., s. 44. 
Akwizgranie (811 r.), Turs (813 r.), Mongucji (813 r.) czy Aix (816 r.). „Wprawdzie dopuszczano malowanie obrazów przedstawiających Chrystusa, jednak uważano, że nie należy oddawać im czci. Wyrażano zgodę na używanie obrazów służących pouczeniu wiernych i ozdobie kościołów, ale nie przypisywano im żadnych liturgicznych funkcji”24.

Później, w okresie Renesansu, zaczęła obowiązywać nowa koncepcja sztuki obrazowej, kierująca ją w stronę naturalizmu i podkreślająca wyższość materii nad duchem, co było następstwem „zastąpienia zmysłu kontemplacji zmysłem obserwacji”. Ówcześni artyści wprowadzili więc do swoich obrazów nie tylko złudzenie trzech wymiarów, ale również zaszyfrowany i trudny do odczytania dla oglądającego przekaz, co w konsekwencji doprowadziło, przez zmianę podmiotu, do zaprzeczenia istoty sztuki sakralnej, ograniczając ją do ukazywania kunsztu artystycznego twórcy ${ }^{25}$. Bowiem taki obraz nie był już w stanie doprowadzić oglądającego wprost do Boga.

\section{ROLA SZTUKI W KOŚCIELE WEDŁUG SOBORU TRYDENCKIEGO I VATICANUM II}

Kwestia kultu obrazów w Kościele Zachodnim stała się szczególnie istotna w świetle tez głoszonych przez ideologów Reformacji, którzy w swoich poglądach na temat miejsca sztuki w kulcie religijnym nawiązywali do postulatów klasycznego obrazoburstwa $^{26}$. Ale nie tylko, bowiem wprowadzone w Renesansie zmiany w koncepcji obrazu sakralnego również miały w tym swój udział.

Dlatego też Sobór Trydencki (obradujący w latach 1545-1563) był odpowiedzią na zmiany w ówczesnym Kościele. „Aby przeciwstawić się skuteczniej nowej nauce ikonoklastów, jaka w tym czasie się pojawiła, na nowo potwierdził swą stałą naukę"27. Sobór ponownie podjął się więc wyjaśnienia sprawy kultu obrazów religijnych. Dokumenty soborowe nakazywały wprost, by w świątyniach były umieszczane obrazy i by oddawano im należny kult i poszanowanie.

W Dekrecie o wzywaniu, czci i relikwiach świętych oraz świętych obrazach z 3 grudnia 1563 roku ojcowie soborowi napisali m.in.: „Obrazy Chrystusa, Bożej Rodzicielki oraz innych świętych należy posiadać i zachowywać zwłaszcza w świątyniach, i oddawać im należną cześć i uszanowanie, nie dlatego by wierzono, że tkwi w nich jakieś bóstwo czy moc, ze względu na które miałyby być czczone;

\footnotetext{
${ }^{24}$ Z. Bator, Problem ikony Chrystusa w liturgii, Teologia w Polsce 23(2005) nr 81, s. 27.

${ }^{25}$ Z. Treppa, Tajemnica widzialności Boga. Szkice z teologii obrazu, dz. cyt., s. 62.

${ }^{26}$ T. Łukaszuk, Ikona $w$ życiu, $w$ wierze $i$ w teologii Kościoła, Kraków 2008, s. 201.

27 Jan Paweł II, List apostolski Duodecimum saeculum, Vox Patrum 10(1990), z. 19, s. 567.
} 
lub że można ich o coś prosić; lub że należy pokładać nadzieję w obrazach, jak niegdyś czynili poganie, którzy swą nadzieję pokładali w bożkach, ale dlatego, że okazywany im honor odnosi się do wzoru, który przedstawiają. W ten sposób przez obrazy, gdy je całujemy, odkrywamy przed nimi głowę i klękamy, adorujemy Chrystusa i czcimy świętych, których one noszą podobizny. Zatwierdziły to sobory, zwłaszcza Sobór Nicejski II przeciwko obrazoburcom. /.../ Gdyby zaś ktoś nauczał lub utrzymywał coś przeciwnego tym dekretom - niech będzie wyklęty"28.

Poprzez potwierdzenie (a nawet prawie dosłowne przytoczenie) postanowień wcześniejszych soborów, szczególnie Niceanum II, Sobór Trydencki oparł swoje rozstrzygnięcia w sprawie kultu obrazów na Tradycji Kościoła. Kwestia ta weszła też do tzw. Trydenckiego wyznania wiary z 1564 roku, opublikowanego we wstępie do Kodeksu Prawa Kanonicznego pt. Wyznanie wiary katolickiej: „Uznaję stanowczo, iż należy mieć i zachowywać obrazy Chrystusa, Najświętszej Panny Matki Bożej i innych świętych oraz oddawać im należną cześć i poszanowanie"29. Jak słusznie zauważył Łukaszuk, „Sobór Trydencki odsunął od obrazów i ich kultu zarzut odradzającego się pogańskiego bałwochwalstwa: tyle, i tylko tyle, można i należy widzieć i czytać w słowach trydenckiego dekretu"30.

Jednak stale postępujące odwracanie się sztuki religijnej od samej wiary, którego przejawy można było zauważyć w Niemczech już w latach 20. XX wieku, doprowadziło w końcu do powstania nowego ikonoklazmu, który bywał postrzegany jako jeden z bodźców do zwołania Soboru Watykańskiego II (1962-1965) ${ }^{31}$. Sobór ten potwierdził orzeczenia Soboru Nicejskiego II odnośnie do kultu obrazów i tematyka ta znalazła się w dwóch dokumentach soborowych: w Konstytucji o liturgii świętej Sacrosanctum Concilium (z 1963 r.), traktującej obrazy jako znaki i symbole rzeczy niebiańskich, oraz Konstytucji dogmatycznej o Kościele Lumen Gentium (z 1964 r.).

28 Dokumenty Soborów Powszechnych, t. 4, oprac. A. Baron, H. Pietras, Kraków 2004, str. 781. I dalej: „Jeżeli zaś czasem wyraża się i przedstawia wydarzenia i opowiadania z Pisma Świętego, co jest stosowne dla nieuczonego ludu, należy pouczyć lud, że Bóstwo nie dlatego zostało przedstawione, jak gdyby mogło być widziane ludzkimi oczyma lub wyrażone barwami i kształtami. Następnie należy usunąć wszelkie przesądy związane z wzywaniem świętych, czczeniem relikwii oraz świętym używaniem obrazów; należy wyeliminować wszelkie brudne zyski i unikać wszelkiej swawoli, aby nie malowano obrazów i nie zdobiono ich bezwstydnym powabem, aby ludzie nie nadużywali uroczystości ku czci świętych i nawiedzania relikwii do uczt i pijaństwa, jak gdyby świąteczne dni ku czci świętych sprowadzały się do przepychu i swawoli. /.../ Aby zasady te wierniej zachowywano, święty sobór postanawia, że nikomu nie wolno w żadnym miejscu ani kościele, nawet w jakikolwiek sposób objętym egzempcją, umieszczać ani starać się o umieszczenie jakiegokolwiek niezwykłego obrazu, jeżeli nie uznał go biskup". Dokumenty Soborów Powszechnych, t. 4, dz. cyt., str. 782n.

${ }_{29}$ Breviarium fidei. Wybór doktrynalnych wypowiedzi Kościoła, oprac. S. Głowa, I. Bieda, Poznań 1989, s. 645.

30 T. Łukaszuk, Ikona $w \dot{z y c i u, ~} w$ wierze $i$ teologii Kościoła, dz. cyt., s. 246.

31 J. Ratzinger, Duch liturgii, tł. E. Pieciul, Poznań 2002, s. 118. 
W pierwszym dokumencie sobór zdefiniował sztukę religijną jako „znaki i symbole najwyższych spraw" i stanowczo nakazał zachowywać zwyczaj umieszczania w świątyniach wizerunków świętych, by wierni mogli oddawać im cześć, „,w ilości wszakże umiarkowanej i we właściwym porządku, aby nie budziły zdziwienia ludu chrześcijańskiego i nie hołdowały mniej właściwej pobożności”32.

Jak zauważył Janusz Pasierb, to ostatnie zastrzeżenie odnośnie do liczby świętych wizerunków w świątyniach Kościoła Zachodniego zostało przez sobór wprowadzone z uwagi na „niepohamowany rozwój ilościowy przedstawień figuralnych”. To z kolei doprowadziło do przekroczenia rozsądnej liczby obrazów o treści religijnej w kościołach i skutkowało sprowadzeniem świętych przedstawień do roli ozdoby.

„Ruch odnowy - jeszcze przed soborem - postulował zapobieżenie tej degeneracji poprzez ograniczenie ilości wizerunków w nowoczesnych wnętrzach kościelnych. Tendencje takie - uzasadnione i słuszne - mogły rodzić także pewne przerysowania prowadzące do ikonoklazmu". Natomiast zupełnie w innej sytuacji znajdowała się od wieków sztuka w Kościele Wschodnim, gdzie była ona (i nadal jest) znakiem obecności łaski Bożej ${ }^{33}$.

Sobór podzielił też sztukę o treści religijnej na sztukę religijną i kościelną (czyli sakralną), która jest „szczytem” sztuki religijnej, a jej przeznaczeniem jest publiczny kult ze strony wiernych, ich religijne kształcenie i zbudowanie.

„Do najszlachetniejszych dzieł ducha ludzkiego słusznie zalicza się sztuki piękne, zwłasz-
cza sztukę religijną i jej szczyt, mianowicie sztukę kościelną. Z natury swej dążą one do
wyrażenia w jakiś sposób w dziełach ludzkich nieskończonego piękna Bożego. Są one
tym bardziej poświęcone Bogu i pomnażaniu Jego czci i chwały, im wyłączniej zmie-
rzają tylko do tego, aby swoimi dziełami dusze ludzkie pobożnie zwracać ku Bogu”34.

Na Soborze Watykańskim II został również podjęty temat przepychu w wystroju świątyń. Konstytucja o liturgii wprost nakazywała biskupom troskę „raczej o szlachetne piękno aniżeli o sam przepych"35. I nie był to żaden nowy problem na łonie Kościoła, gdyż już w IV wieku Epifaniusz z Salaminy uważał, że zasłony w świątyniach, na których malowano wizerunki świętych powinno się oddać ubogim na prześcieradła ${ }^{36}$.

Natomiast Konstytucja dogmatyczna o Kościele Lumen Gentium już na samym początku przytacza słowa Listu do Kolosan, że Chrystus ,jest obrazem Boga

${ }^{32}$ Konstytucja o liturgii świętej Sacrosanctum Concilium, 125.

33 J. Pasierb, Teoria sztuki sakralnej w postanowieniach Vaticanum II, w: Collectanea Theologica, 40 (1970), III, s. 20n. Trzeba podkreślić, że w nowej instrukcji Ordo Missae zostało zawarte ograniczenie, że w świątyni „nie powinno się umieszczać więcej niż jednego obrazu tego samego świętego”.

${ }^{34}$ Konstytucja o liturgii świętej Sacrosanctum Concilium, 122. Zob. też J. Pasierb, Teoria sztuki sakralnej w postanowieniach Vaticanum II, dz. cyt., s. 7, 9.

35 Tamże, 124.

36 J. Pasierb, Teoria sztuki sakralnej w postanowieniach Vaticanum II, dz. cyt., s. 13. 
niewidzialnego" ${ }^{37}$. Kwestia obrazów pojawiła się w tym dokumencie jeszcze raz, przy okazji rozdziału o kulcie Błogosławionej Dziewicy w Kościele. „Sobór święty umyślnie podaje do wiadomości tę katolicką naukę, napominając równocześnie wszystkich synów Kościoła, aby szczerze popierali kult Błogosławionej Dziewicy, szczególnie liturgiczny, a praktyki i zbożne ćwiczenia ku Jej czci zalecane w ciągu wieków przez Urząd Nauczycielski cenili wysoko i to, co postanowione było w minionych czasach o kulcie obrazów Chrystusa, Błogosławionej Dziewicy i Świętych, pobożnie zachowywali”38.

\section{KULT OBRAZÓW W PRAWIE KANONICZNYM I KATECHIZMIE}

Później kwestię kultu obrazów Kościół podjął jeszcze w Kodeksie Prawa Kanonicznego, Kodeksie Kanonów Kościołów Wschodnich i Katechizmie Kościoła Katolickiego. Kodeks Prawa Kanonicznego dokładnie powtarza słowa Konstytucji Sacrosanctum Concilium i nakazuje, aby zachować praktykę umieszczania w kościołach świętych obrazów, by doznawały czci ze strony wiernych ${ }^{39}$. Podobnie czyni to Kodeks Kanonów Kościołów Wschodnich ${ }^{40}$.

Katechizm z kolei poświęcił świętym obrazom więcej miejsca. Punktem wyjścia było tu oczywiście Wcielenie Chrystusa, który, przyjmując ludzkie ciało i stając się prawdziwym człowiekiem, przyjął także jego ograniczenia. „Na tej podstawie ludzkie oblicze Jezusa może być ,przedstawiane'. Na siódmym soborze powszechnym Kościół uznał za dozwolone ukazywanie go na świętych obrazach"»1.

Dalej Katechizm wyjaśnił i potwierdził, że ,indywidualne cechy ciała Chrystusa rzeczywiście wyrażają Boską Osobę Syna Bożego. Uczynił On swoimi rysy swojego ludzkiego ciała do tego stopnia, że namalowane na świętym obrazie mogą być otaczane kultem, ponieważ wierzący, który czci Jego obraz, ,czci osobę, którą obraz przedstawia" "ม2. Dodał także, że kult świętych obrazów nie jest sprzeczny

37 Konstytucja dogmatyczna o Kościele Lumen Gentium, KK 2, 7. Zob. też Kol 1, 15.

38 Tamże, KK 67.

39 Kodeks Prawa Kanonicznego (Codex Iuris Canonici z 1983 r.), Pallottinum 2008, kan. 1188: „Należy zachować praktykę umieszczania w kościołach świętych obrazów, by doznawały czci ze strony wiernych; jednakże mają być umieszczane w umiarkowanej liczbie i z zachowaniem właściwego porządku, aby nie wywoływały zdziwienia u wiernych i nie dawały okazji do niewłaściwej pobożności”.

40 Kodeks Kanonów Kościołów Wschodnich (Codex Canonum Ecclesiarum Orientalium z 1990 r.), Lublin 2002, kan. 886: „Należy zachować praktykę umieszczania w kościołach świętych ikon lub obrazów, by doznawały czci ze strony chrześcijan, według sposobu i porządku ustanowionego prawem partykularnym własnego Kościoła sui iuris".

41 Katechizm Kościoła Katolickiego, Pallottinum 1994, 476.

42 Tamże, 477. 
z pierwszym przykazaniem, które przestrzega wiernych przed bałwochwalstwem, gdyż już w Starym Testamencie, pozostając w zgodzie z prawem, można było tworzyć pewne znaki, jak np. węża miedzianego, Arkę Przymierza czy wizerunki cherubinów, które to ,w sposób symboliczny miały doprowadzić do zbawienia przez Słowo Wcielone”43. „Istotnie ,cześć oddawana obrazowi odwołuje się do pierwotnego wzoru' i ,kto czci obraz, ten czci osobę, którą obraz przedstawia'. Cześć oddawana świętym obrazom jest ,pełną szacunku czcią’, nie zaś uwielbieniem należnym jedynie samemu Bogu"44.

Katechizm Kościoła Katolickiego powiązał również święte obrazy z liturgią, wprowadzając pojęcie ,ikony liturgicznej”, którą jest święty wizerunek przedstawiający przede wszystkim Chrystusa. „Nie może ona przedstawiać niewidzialnego i niepojętego Boga; dopiero Wcielenie Syna Bożego zapoczątkowało nową ,ekonomię’ obrazów" i umożliwiło przedstawianie na obrazach zarówno Jego wizerunku, jak i Matki Bożej oraz świętych ${ }^{45}$. Przez te przedstawienia, szczególnie ostatnie dwa, ,objawia się naszej wierze człowiek ,na obraz Boga’, przemieniony wreszcie „na Jego podobieństwo', a nawet aniołowie, włączeni także w dzieło Chrystusa"46.

Wyraźnie została zaznaczona także komunikacyjna rola obrazów i całej ikonografii chrześcijańskiej, które stanowiąc formę symbolu ${ }^{47}$ wyrażają „orędzie ewangeliczne, które Pismo święte opisuje za pośrednictwem słów. Obraz i słowo wyjaśniają się wzajemnie" ${ }^{48}$. Jest to szczególnie aktualne dzisiaj, kiedy masowe media elektroniczne skazały nas właśnie na kulturę obrazów. Stąd sama liturgia, w której zwierają się widzialne symbole, muzyka i śpiew ma znaczący udział w kształtowaniu religijności i przekazie Dobrej Nowiny, czyli w komunikowaniu prawd wiary. ,Czyż nie jest więc wielką szkodą (i krzywdą wyrządzaną zwłaszcza ludziom młodym), że właśnie w erze ,obrazu’ nasza liturgia sprowadza się przeważnie do samej tylko ,liturgii słowa’? Czy nie w tym właśnie tkwi największy brak dotyczący aktualnego doświadczenia liturgii?" - słusznie pytał Stefaan van Calster ${ }^{49}$.

Idąc dalej, można w tym miejscu zapytać również, jaka powinna być zatem „dobra" liturgia? W powyższym kontekście powinna ona bardzo wyraźnie eksponować

\footnotetext{
43 Tamże, 2130.

44 Tamże, 2132.

45 Tamże, 1159, 2131.

46 Tamże, 1161.
}

47 Zastosowanie w ikonie języka symboli pozwalało z jednej strony na komunikowanie wiernym w zrozumiały i prosty sposób treści wcześniej niemożliwych do przekazania, natomiast z drugiej strony pozwalało na ukrycie pewnych tajemnic wiary przed katechumenami, którzy nie byli jeszcze dostatecznie przygotowani, by je pojąć. Zob. K. Matwiejuk, Ikona - okno ku transcendencji, Warszawskie Studia Pastoralne UKSW 13/2011, s. 154. Szerzej na temat symbolu jako sposobu komunikowania Objawienia zob. też: K. Matwiejuk, Ikona jako komunikator treści zbawczych, Teologiczne Studia Siedleckie X(2013)10, s. 82-87.

48 Katechizm Kościoła Katolickiego, dz. cyt., 1160.

49 S. van Calster, Liturgia jako uprzywilejowane miejsce przekazywania wiary, Communio 5/2002, s. 114 . 
nie tyle słowo mówione, ale przede wszystkim elementy, które bądź to przynależą do kultury obrazu, bądź też stanowią jej uzupełnienie, tworząc wspólnie efektywne miejsce przekazywania wiary. Chodzi tu m.in. o obraz, symbol, kolor, ale także o gest, śpiew czy muzykę. Rolą liturgii powinno być przede wszystkim skuteczne oddziaływanie na świadomość, a nawet podświadomość zgromadzonych na niej wiernych, czego efektem będzie lepsza komunikacja wiary, dzięki czemu sama liturgia stanie się swego rodzaju katechezą ${ }^{50}$.

Ważne jest, jak zauważył Kazimierz Wolny-Zmorzyński za Edwardem Hallem, by odbiorcy komunikatów wizualnych nauczyli się je odczytywać „,równie łatwo, jak drukowane i mówione" ${ }^{51}$. Stąd Jacek Dąbała, przytaczając słowa Stanisława Lema, postuluje, by tajemnicę Boga wyrażać przede wszystkim w sposób zrozumiały dla współczesnego człowieka, by nie tylko „miał wrażenie, że odnajduje w niejasności jakiś wyższy sens ${ }^{52}$, ale również uczestniczy w czymś wyjątkowym ${ }^{53}$. „Ta odmiana tajemnicy ze swojej istoty jest właśnie taka: wymaga - od strony twórcy głównie przez porządkujący charakter - odkrywania i poszukiwania swojej niepojętności środkami dostępnymi człowiekowi, korzystania z elementów bytu, w których zmysły i rozum odbiorcy odnajdują przynajmniej namiastkę odpowiedzi na wyrażone wątpliwości" ${ }^{4}$.

Wspomniana wyżej obecność obrazów w liturgii ma jeszcze jedną korzyść - w ten sposób Kościół komunikuje naukę Chrystusa językiem zrozumiałym zwłaszcza dla ludzi młodych, którzy właściwie od urodzenia żyją w świecie mass mediów, dla których podstawowym nośnikiem informacji jest obraz ${ }^{55}$.

Dlatego też, jak podkreślił Katechizm, kontemplacja świętych obrazów znajdujących się w świątyni, włączonych w akcję liturgiczną, w połączeniu z medytacją słowa Bożego oraz śpiewem liturgicznym, ,należy do harmonii znaków celebracji, aby celebrowanie misterium wycisnęło się w pamięci serca, a następnie znalazło swój wyraz w nowym życiu wiernych" ${ }^{56}$. Dalej Katechizm Kościoła Katolickiego wyjaśnił, na czym polegają komunikacyjne i ewangeliczne możliwości sztuki. „Sztuka sakralna jest prawdziwa i piękna, gdy przez formę odpowiada swojemu właściwemu powołaniu, jakim jest ukazywanie i uwielbianie, w wierze i adoracji, transcendentnej tajemnicy Boga, niewidzialnego, najwyższego piękna Prawdy i Miłości, objawionego w Chrystusie, ,który jest odblaskiem Jego chwały i odbiciem Jego istoty' (Hbr 1, 3), w którym ,mieszka cała Pełnia: Bóstwo, na sposób ciała' (Kol 2, 9). To duchowe piękno odzwierciedla się także w Najświętszej Maryi

50 Tamże, s. 114 n.

51 K. Wolny-Zmorzyński, Fotograficzne gatunki dziennikarskie, Warszawa 2007, s. 41.

52 J. Dąbała, Tajemnica $i$ suspens $w$ sztuce pisania. W kregu retoryki dziennikarskiej $i$ dramaturgii medialnej, Toruń 2010, s. 155.

53 J. Dąbała, Tajemnica $i$ suspens $w$ sztuce pisania, dz. cyt., s. 181.

54 Tamże, s. 155.

55 Tamże, s. 120.

${ }^{56}$ Katechizm Kościoła Katolickiego, dz. cyt., 1162. 
Dziewicy, Matce Boga, w Aniołach i Świętych. Prawdziwa sztuka sakralna skłania człowieka do adoracji, modlitwy i miłowania Boga Stwórcy i Zbawiciela, Świętego i Uświęcającego" 57 . W Katechizmie zaznaczono również, że święte obrazy mogą być skuteczną pomocą w kontemplacji oraz modlitwie i to zarówno prywatnej, jak i wspólnotowej ${ }^{58}$.

Jednak należy mieć się na baczności, by nie zboczyć z tej właściwej drogi - upomina Kościół. Kongregacja ds. Kultu Bożego i Dyscypliny Sakramentów w Dyrektorium o pobożności ludowej $i$ liturgii przestrzegła więc wyraźnie, że „cześć dla świętych wizerunków, jeśli nie pochodzi z jasnej wizji teologicznej, może prowadzić do dewiacji” ${ }^{59}$. Dalej zaznaczyła też, że „zadaniem świętego wizerunku nie jest przede wszystkim dostarczenie przyjemności estetycznej, lecz wprowadzenie w misterium. Czasem jednak aspekt estetyczny staje się czymś najważniejszym, a wówczas obraz przyjmuje funkcje raczej ,tematu’ artystycznego, a nie nośnika przekazu duchowego" ${ }^{\prime 60}$.

\section{PAPIEŻE O SZTUCE}

Na liturgiczną funkcję świętych obrazów zwrócił też uwagę kardynał Joseph Ratzinger, późniejszy papież Benedykt XVI, w swojej książce Duch liturgii, pisząc o ikonie, że jest ona przyporządkowana misterium, które ma swoje uobecnienie w liturgii, i jest skierowana ku liturgii niebiańskiej ${ }^{61}$, a ,jej dynamika jest w całości tożsama z dynamiką liturgii. Jej chrystologia jest trynitarna - to Duch Święty czyni nas widzącymi, to Jego działanie wywołuje w nas zawsze ruch w kierunku Chrystusa" ${ }^{\text {"2 }}$. Obrazy wskazują na sakrament, w szczególności na chrzest i Eucharystię, i „poprzez wspólne odniesienie do sakramentu łączą się w nim, wyrażając tym samym wymiar teraźniejszości” i są ściśle związane z akcją liturgiczną ${ }^{63}$. Sztuka służy

57 Tamże, 2502 .

58 Tamże 2691, 2705.

${ }^{59}$ Kongregacja ds. Kultu Bożego i Dyscypliny Sakramentów, Dyrektorium o pobożności ludowej i liturgii, Poznań 2003, nr 239.

${ }_{60}$ Tamże, nr 243. Wspólne elementy liturgii i przedstawienia teatralnego przedstawił m.in. M. Masłowski w swoim artykule Msza święta jako przedstawienie, w: Ikony Niewidzialnego, red. M. Lis, Z. W. Solski, Opole 2003, s. 81-100. Jest to bardzo interesujący i wart późniejszego pogłębienia temat, szczególnie w kontekście komunikacji wizualnej w przekazie wiary. Pozwala odkryć inne aspekty całego rytuału, na które wcześniej zwykle w ogóle nie zwracało się uwagi, chodzi np. o interpretację gestów w połączeniu z wypowiadanymi słowami czy znaczenie samego miejsca akcji i występujących tam ,dekoracji”.

${ }^{61}$ J. Ratzinger, Duch liturgii, dz. cyt., s. 114.

${ }_{62}$ Tamże, s. 111.

${ }^{63}$ Tamże, s. 120. 
więc liturgii, z kolei „modlitwa i spojrzenie, w którym formują się obrazy, musi być zatem współmodleniem się i współpatrzeniem wraz z widzącą wiarą Kościoła" ${ }^{64}$.

Jak podkreślił kard. Ratzinger, „całkowity brak obrazów nie daje się pogodzić z wiarą we wcielenie Boga. /.../ Ikonoklazm nie jest opcją chrześcijańską ${ }^{65 \%,}$ jest natomiast sumą wszystkich herezji ${ }^{66}$. Postuluje również, by Kościół Zachodni rzeczywiście przyjął naukę Soboru Nicejskiego II na temat roli i miejsca obrazów w nauczaniu Kościoła ${ }^{67}$.

Jednak najbardziej wyczerpującym dokumentem na temat roli i miejsca sztuki w Kościele jest List do artystów Jana Pawła II. Papież w swoich rozważaniach wyszedł od istoty powołania do bycia artystą, który poszukuje „,nowych ,epifanii' piękna, aby podarować je światu w twórczości artystycznej”68. O ważności tego szczególnego powołania może świadczyć choćby samo określenie „twórca”, które ma wiele wspólnego ze słowem „stwórca”, z tą jednak różnicą, że stwórca tworzy coś z niczego, natomiast twórca z rzeczy już istniejących ${ }^{69}$.

Dalej Jan Paweł II podkreślił, że owocem przymierza Ewangelii i każdej autentycznej formy sztuki jest możliwość wprowadzenia człowieka w odpowiednią perspektywę wiary, w której może on znaleźć najpełniejszą interpretację doświadczenia, swego rodzaju drogę dostępu „do głębszej rzeczywistości człowieka i świa$\operatorname{ta}{ }^{70}$. „Sztuka bowiem, jeżeli jest autentyczna, /. . ./, zachowuje więź wewnętrznego pokrewieństwa ze światem wiary, tak że nawet w sytuacji głębokiego rozłamu między kulturą a Kościołem właśnie sztuka pozostaje swego rodzaju pomostem prowadzącym do doświadczenia religijnego" ${ }^{\text {. }}$. Natomiast na Wschodzie ikona stała się poniekąd sakramentem, ponieważ poprzez zmysł wzroku uobecnia tajemnicę Wcielenia, w sposób analogiczny do tego, jak uobecniają ją sakramenty ${ }^{72}$.

Zatem - jak zauważył papież - Kościół bezwzględnie potrzebuje sztuki. Przede wszystkim po to, by skutecznie głosić naukę Chrystusa poprzez ukazywanie na obrazach rzeczywistości duchowej w formie zrozumiałej, a szczególnie atrakcyjnej dla współczesnego człowieka. „Otóż sztuka odznacza się sobie tylko właściwą zdolnością ujmowania wybranego aspektu tego orędzia, przekładania go na język barw, kształtów /.../, które wspomagają intuicję człowieka patrzącego /.../. Czyni to, nie odbierając samemu orędziu wymiaru transcendentnego ani aury tajemnicy" ${ }^{73}$.

\footnotetext{
64 Tamże, s. 121.

65 Tamże, s. 119.

66 Tamże, s. 111.

67 Tamże, s. 121.

68 Jan Paweł II, List do artystów, Watykan 1999, wstęp.

69 Tamże, 1.

70 Tamże, 6, 14.

71 Tamże, 10.

72 Tamże, 8. Zob. też J. Ratzinger, Duch liturgii, dz. cyt., s. 108n oraz M. Pyc, Chrystologiczna argumentacja $w$,Mowach obronnych przeciw tym, którzy odrzucaja święte obrazy” Jana Damasceńskiego, dz. cyt., s. 166.

73 Tamże, 12.
} 
Jan Paweł II w Liście apostolskim Rosarium Virginis Mariae, poświęconym modlitwie różańcowej, zwrócił też uwagę na kontemplacyjną rolę świętych obrazów, poniekąd dowartościowując sztukę religijną w wymiarze praktycznym ${ }^{74}$. Zalecał, by odmawiając różaniec czynić to przed ikoną przedstawiającą daną tajemnicę. „Zapowiedź tajemnicy i, jeśli tylko możliwe, równoczesne ukazanie przedstawiającej ją ikony, to jakby odsłonięcie sceny, na której należy skupić uwagę. Słowa kierują wyobraźnię i ducha ku temu określonemu wydarzeniu czy momentowi z życia Chrystusa. W duchowości, która rozwinęła się w Kościele, czy to kult ikon, czy liczne nabożeństwa bogate $\mathrm{w}$ elementy postrzegane zmysłami, jak również metoda zaproponowana przez św. Ignacego z Loyoli w Ćwiczeniach duchownych odwoływały się do elementu wzrokowego i obrazowego (compositio loci), uważając go za bardzo pomocny w koncentracji ducha na misterium. Jest to zresztą metodologia, która odpowiada samej logice Wcielenia: Bóg zechciał przyjąć w Jezusie rysy ludzkie. To przez Jego fizyczną rzeczywistość zostajemy doprowadzeni do kontaktu z Jego Boską tajemnicą"75.

Powyższą propozycję włączenia świętych ikon do modlitwy kontemplacyjnej można odczytać nie tylko jako gest ekumeniczny, ale przede wszystkim jako prosty i wyjątkowo skuteczny sposób na pogłębienie życia duchowego współczesnego chrześcijanina $^{76}$.

Z kolei w Liście apostolskim Duodecimum saeculum wydanym z okazji 1200 rocznicy II Soboru Nicejskiego Jan Paweł II postulował większe wykorzystanie świętych obrazów w ewangelizacji wiernych ze względu na to, że stale „rośnie zapotrzebowanie na jakiś język duchowy, którym posługuje się autentyczna sztuka chrześcijańska" i zachęcał biskupów do przestrzegania postanowień Soboru Nicejskiego $\mathrm{II}^{77}$. Dlaczego jest to tak istotny problem szczególnie w naszych czasach? Jan Paweł II trafnie i ponadczasowo stwierdził, że „to właśnie nowe odkrycie obrazu chrześcijańskiego przyczyni się zapewne także do uświadomienia sobie przez ludzi, jak bardzo konieczną rzeczą jest przeciwdziałanie niszczącym, a częściej degradującym osobę ludzką skutkom skutkom owych wielorakich obrazów, które oddziałują na nasze życie poprzez publikacje i środki społecznego przekazu. Obrazem bowiem jest to, co przybliża nam postać niewidzialnego Twórcy oraz otwiera nam dostęp do rzeczy duchowych i eschatologicznych"78. Podkreślił również wartość ekumeniczną orzeczeń Niceanum II, co „stanowi zarówno dla nas katolików, jak też dla naszych braci prawosławnych mocną zachętę do tego, abyśmy na nowo wspólnie przyjrzeli się drodze tradycji Kościoła nie podzielonego. W jej

${ }^{74}$ Z. Bator, Ikony a kontemplacja. Znaczenie i funkcje świętych wizerunków w modlitwie wedlug Ojców Kościoła, Duchowość w Polsce 16(2014), s. 205.

75 Jan Paweł II, List apostolski Rosarium Virginis Mariae, Watykan 2002, 29.

${ }^{76} \mathrm{Z}$. Bator, Ikony a kontemplacja. Znaczenie i funkcje świętych wizerunków w modlitwie wedlug Ojców Kościoła, dz. cyt., s. 205.

77 Jan Paweł II, List apostolski Duodecimum saeculum, dz. cyt., s. 567.

78 Tamże, s. 568. 
świetle przypatrzmy się ponownie różnicom, które narosły między nami w ciągu wieków podziału. To wszystko zaś po to, by znaleźć w widzialnej jedności pełne zjednoczenie, o jakie Jezus prosił Ojca (J 17, 11; 20-21)" "79.

Natomiast w Tryptyku Rzymskim ów papież po raz kolejny potwierdził, że głoszone przez Pismo Święte słowo czeka na obraz, bowiem słowo i obraz wzajemnie się wyjaśniają, uzupełniają. „Stoję przy wejściu do Sykstyny - Może to wszystko łatwiej było wypowiedzieć językiem ,Księgi Rodzaju’ - Ale Księga czeka na obraz. - I słusznie. Czekała na swego Michała Anioła. Przecież ten, który stwarzał, ,widział' - widział, że ,było dobre'. ,Widział', a więc Księga czekała na owoc ,widzenia'. O ty, człowieku, który także widzisz, przyjdź - Przyzywam was wszystkich ,widzących' wszechczasów. Przyzywam ciebie, Michale Aniele! Jest w Watykanie kaplica, która czeka na owoc twego widzenia! Widzenie czekało na obraz. Odkąd Słowo stało się ciałem, widzenie wciąż czeka"80.

We współczesnej teologii katolickiej coraz większe znaczenie zaczyna więc odgrywać teologia piękna, która opiera się na „wierze z patrzenia" ${ }^{11}$. Problematykę fides ex visu poruszył m.in. papież Franciszek w encyklice Lumen fidei. Jego zdaniem wiara powinna być zarówno „słuchaniem”, jak i „widzeniem”, gdyż obie te drogi nie wykluczają się wzajemnie, tylko uzupełniają, będąc pełnoprawnymi i równorzędnymi sposobami dotarcia do Boga.

O wzajemnym związku słuchania i widzenia w poznawaniu Objawienia papież napisał: „Dzięki temu zespoleniu ze słuchaniem widzenie staje się pójściem za Chrystusem, a wiara jawi się jako droga widzenia, na której oczy przyzwyczajają się do spoglądania w głąb. I tak, w poranek wielkanocny, od Jana, który gdy jeszcze było ciemno, przed pustym grobem »ujrzał i uwierzył (J 20, 8), przechodzimy do spojrzenia Marii Magdaleny, która już widzi Jezusa (por. J 20, 14) i chce Go zatrzymać, ale zostaje zachęcona do kontemplowania Go na Jego drodze do Ojca, aż do pełnego wyznania samej Magdaleny wobec uczniów: »Widziałam Pana« (J 20, 18). Jak można osiągnąć tę syntezę słuchania i widzenia? Staje się to możliwe, gdy bierzemy za punkt wyjścia konkretną osobę Jezusa, którego widzimy i słuchamy. On jest Słowem, które stało się ciałem, którego chwałę oglądaliśmy (por. J 1, 14). Światło wiary jest światłem Oblicza, w którym widać Ojca" ${ }^{2}$.

Zatem, jak widać, między lectio (słowo) i visio (obraz) Divina w duchowości chrześcijańskiej zachodzi paralelizm. Co więcej, nawet wzajemnie się przenikają. „Lectio pozwala widzieć, a visio stanowi interpretacyjny kontekst dla lectio" ${ }^{\text {. }}$.

79 Tamże, s. 560.

80 Jan Paweł II, Tryptyk rzymski, Kraków 2003, s. 16n.

81 Temat ten dość szczegółowo omówił R. Chałupniak w artykule „Fides ex visu” we wspótczesnej teologii piękna, Colloquia Theologica Ottoniana 1/2014, s. 151-175.

82 Franciszek, Encyklika Lumen fidei, Rzym 2013, 30.

${ }^{83}$ K. Klauza, Lectio czy visio Divina?, w: Lectio divina, red. J. M. Popławski, Lublin 2008, s. 75. 
VIA PULCHRITUDINIS, CZYLI DROGA PIĘKNA

Na koniec zatrzymajmy się przez chwilę nad obrazem jako interpretacją prawd wiary, nośnikiem treści teologicznej i czynnikiem kształtującym naukę chrześcijańską,

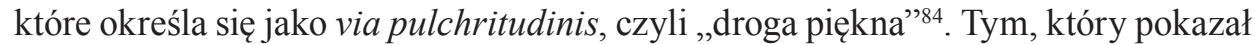
niezaprzeczalną wartość piękna w przyswajaniu prawd wiary chrześcijańskiej był Hans Urs von Balthasar. W swojej kilkutomowej pracy Chwała ${ }^{85}$ dał kompletny wykład estetyki teologicznej ${ }^{86}$.

Zadaniem via pulchritudinis jest właściwe odczytywanie obrazu religijnego, swoiste objaśnienie estetyki świętego wizerunku w kontekście teologii. Powinna ona stać się przede wszystkim sposobem wyrażania nieskończonego tak jak Bóg piękna, przez które Kościół głosi Dobrą Nowinę, „stojąc mocno na gruncie Biblii i dogmatu" ${ }^{87}$. Wierni z kolei mają w ten sposób do dyspozycji jedną z alternatywnych dróg poznawania Boga, którą mogą ku Niemu podążać.

Warto również przypomnieć, że Papieska Rada ds. Kultury w 2006 r. w dokumencie Via Pulchritudinis zaproponowała refleksję nad „drogą piękna” jako skuteczny sposób ewangelizacji oraz narzędzie dialogu z niewierzącymi ${ }^{88}$. Jednak, aby te działania były efektywne, trzeba najpierw nauczyć się języka odbioru sztuki, by móc później przyjąć i zrozumieć piękno. Ponadto - jak podkreśliła Rada - dopiero taka odpowiednia kontemplacja dzieł sztuki może przyczynić się do umiłowania modlitwy ${ }^{89}$.

\section{SKUTECZNA KOMUNIKACJA WIARY DZIĘKI OBRAZOM}

Podsumowując, trzeba zatem zaznaczyć, że owocne przekazywanie wiary potrzebuje dziś nie tyle słów, co przede wszystkim obrazów, dzięki którym współczesnemu człowiekowi łatwiej będzie przyswoić i zrozumieć treść Dobrej Nowiny. Dlatego też nie należy zapominać o katechetycznej funkcji świętych wizerunków. „Obrazy

${ }^{84}$ J. Królikowski, Chrystologia i obraz w Kościele, dz. cyt., s. 81.

${ }^{85}$ H. U. von Balthasar, Chwała. Estetyka teologiczna, tł. J. Fenrychowa, L. Łysień, E. Marszał, J. Zakrzewski, t. 1-3, Kraków 2007-2013.

${ }^{86}$ J. Lekan, Maryja ikona Chrystusa - „Nowego Człowieka”. Via pulchritudinis w mariologii, Roczniki Teologiczne, 61(2014) z. 2, s. 84.

87 J. Królikowski, Chrystologia i obraz w Kościele, dz. cyt., s. 89.

${ }^{88}$ Papieska Rada ds. Kultury, The Via Pulchritudinis, Privileged Pathway for Evangelisation and Dialogue, Watykan 2006, http://www.vatican.va/roman_curia/pontifical_councils/cultr/documents/ rc_pc_cultr_doc_20060327_plenary-assembly_final-document_en.html (5.05.2015).

${ }^{89}$ Tamże, III, 2 B-C. 
dają taką możliwość, a nawet - mając na uwadze aktualny cywilizacyjny kontekst - nakładają osobliwą konieczność posłużenia się nimi, by skutecznie dotrzeć do współczesnego odbiorcy. Wszelkie wizualizacje odkrywanych i przyswajanych rzeczywistości stanowią dla wychowawców religijnych wyzwanie, jak przekaz religijny uplastycznić, jak także w ten sposób otwierać przed ludźmi XXI w. ,bramę wiary" "90.

Na niewystarczalność słowa w dzisiejszej komunikacji wiary zwrócił też uwagę homileta ks. Leszek Kuc, autor traktatu o teologii komunikacji, który pisał, że wprawdzie ,język słowny odgrywa w tym przekazie również swoistą rolę", mimo to słowa „prowadzą czasami do nieporozumień zamiast do zrozumienia”, a nawet niekiedy „bywają zbędne”. Poza tym „nie wszystko /.../ da się wypowiedzieć słowami"

Jednak, jak zauważył cytowany przez Jacka Dąbałę medioznawca Zbigniew Bauer, mówienie o teologii we współczesnych mediach, w dodatku ich językiem, może powodować, że mistyka stanie się w pewnym sensie „ucodzienniona”, co może być dla niektórych przedstawicieli Kościoła poważnym problemem teologicznym ${ }^{92}$. Niezależnie od tego niebezpieczeństwa trzeba podkreślić, że jest to w dzisiejszych czasach najskuteczniejsza forma dotarcia do masowego odbiorcy, zwłaszcza młodego, gdyż ten rodzaj komunikacji - oczywiście prowadzony w odpowiedni sposób ${ }^{93}$ - potrafi „oczarować” rzesze wiernych ${ }^{94}$. Jednak, niejako przy okazji, „zmienia się tutaj również rozumienie oczarowania; nie jest to już oczywisty wymiar rozrywkowy i komercyjny, lecz głęboki i przejmujący, głównie duchowy, metafizyczny i egzystencjalny"95. A to może już spełniać swoją duchową rolę, jak trafnie ujął Karol Klauza, stanowiąc „kolejny stopień spirali duchowego rozwoju człowieka” ${ }^{\circ}$.

\section{BIBLIOGRAFIA}

Balthasar H. U. von, Chwała. Estetyka teologiczna, tł. J. Fenrychowa, L. Łysień, E. Marszał, J. Zakrzewski, t. 1-3, Kraków 2007-2013.

Bator Z., Ikony a kontemplacja. Znaczenie i funkcje świętych wizerunków w modlitwie wedlug Ojców Kościoła, Duchowość w Polsce 16(2014).

Bator Z., Problem ikony Chrystusa w liturgii, Teologia w Polsce 23(2005) nr 81.

Belting H., Antropologia obrazu. Szkice do nauki o obrazie, tł. M. Bryl, Kraków 2007.

Breviarium fidei. Wybór doktrynalnych wypowiedzi Kościoła, oprac. S. Głowa, I. Bieda, Poznań 1989. Calster S. van, Liturgia jako uprzywilejowane miejsce przekazywania wiary, Communio 5/2002.

90 R. Chałupniak, Arcydzieła malarstwa w katechezie, Opole 2013, s. 196.

${ }^{91}$ L. Kuc, Krótki traktat o teologii komunikacji, Leszno k. Błonia 1997, s. 36n.

92 J. Dąbała, Media i dziennikarstwo. Aksjologia-Warsztat-Tożsamość, Kraków 2014, s. 50n.

${ }^{93}$ Tamże, s. 59-61.

94 Tamże, s. 57.

95 Tamże.

${ }^{96}$ K. Klauza, Telewizja jako miejsce teologiczne, w: Religijny wymiar telewizji, Olsztyn 1990, s. 37. 
Chałupniak R., „Fides ex visu” we współczesnej teologii piękna, Colloquia Theologica Ottoniana $1 / 2014$.

Chałupniak R., Arcydzieła malarstwa w katechezie, Opole 2013.

Chudzikowska-Wołoszyn M., Księgi karolińskie - frankońska odpowiedź na Sobór Nicejski II z roku 787, Studia Warmińskie XLIV-XLV (2007-2008).

Dąb-Kalinowska B., Ruska teologia ikony w polemice z heretykami, w: B. Dąb-Kalinowska, Ikony i obrazy, Warszawa 2000.

Dąbała J., Media i dziennikarstwo. Aksjologia - Warsztat - Tożsamość, Kraków 2014.

Dąbała J., Tajemnica i suspens $w$ sztuce pisania. W kręgu retoryki dziennikarskiej i dramaturgii medialnej, Toruń 2010.

Dokumenty Soborów Powszechnych, t. 2, t. 4, oprac. A. Baron, H. Pietras, Kraków 2003-2004.

Franciszek, Encyklika Lumen fidei, Rzym 2013.

Gero S., The Libri Carolini and the image controversy, The Greek Orthodox Theological Review (1973) nr 1-2.

Jan Paweł II, List apostolski Duodecimum saeculum, Vox Patrum 10(1990), z. 19.

Jan Paweł II, List apostolski Rosarium Virginis Mariae, Watykan 2002.

Jan Paweł II, List do artystów, Watykan 1999.

Jan Paweł II, Tryptyk rzymski, Kraków 2003.

Katechizm Kościoła Katolickiego, Pallottinum 1994.

Klauza K., Lectio czy visio Divina?, w: Lectio divina, red. J. M. Popławski, Lublin 2008.

Klauza K., Telewizja jako miejsce teologiczne, w: Religijny wymiar telewizji, Olsztyn 1990.

Klauza K., Teologiczna hermeneutyka ikony, Lublin 2002.

Kodeks Kanonów Kościołów Wschodnich (Codex Canonum Ecclesiarum Orientalium z 1990 r.), Lublin 2002.

Kodeks Prawa Kanonicznego (Codex Iuris Canonici z 1983 r.), Pallottinum 2008.

Kongregacja ds. Kultu Bożego i Dyscypliny Sakramentów, Dyrektorium o pobożności ludowej i liturgii, Poznań 2003.

Konstytucja dogmatyczna o Kościele Lumen Gentium.

Konstytucja o liturgii świętej Sacrosanctum Concilium.

Królikowski J., Chrystologia i obraz w Kościele, w: Tenże, Nieme słowo. Teologia w sztuce, Tarnów 2008.

Kuc L., Krótki traktat o teologii komunikacji, Leszno k. Błonia 1997.

Lekan J., Maryja ikona Chrystusa - ,Nowego Człowieka”. Via pulchritudinis w mariologii, Roczniki Teologiczne, 61(2014) z. 2.

Libri Carolini (Contra synodum quae in partibus Graeciae pro adorandis imaginibus stolide sive arroganter gesta est), PL 98, 999 D-1248.

Łukaszuk T., Ikona w życiu, w wierze $i$ w teologii Kościoła, Kraków 2008.

Mansi J. D., Sacrorum conciliorum nova et amplissima collectio, t. 13, Florentiae 1767.

Masłowski M., Msza święta jako przedstawienie, w: Ikony Niewidzialnego, red. M. Lis, Z. W. Solski, Opole 2003.

Matwiejuk K., Ikona - okno ku transcendencji, Warszawskie Studia Pastoralne UKSW 13/2011.

MatwiejukK., Ikona jako komunikator treści zbawczych, Teologiczne Studia Siedleckie X(2013)10. Opus Caroli regis contra synodum (Libri Carolini), wyd. A. Freeman, Hannover 1998.

Papieska Rada ds. Kultury, The Via Pulchritudinis, Privileged Pathway for Evangelisation and Dialogue, Watykan 2006, http://www.vatican.va/roman_curia/pontifical_councils/cultr/documents/rc_pc_cultr_doc_20060327_plenary-assembly_final-document_en.html (5.05.2015).

Pasierb J., Teoria sztuki sakralnej w postanowieniach Vaticanum II, w: Collectanea Theologica, 40 (1970), III. 
Pokorska M., „Cibus oculorum”. Uwagi o teorii dzieła sztuki w „Libri Carolini”, Folia Historiae Artium, T. XXVII (1991).

Pyc M., Misterium Chrystusa w centrum debaty nad ikonami na Soborze Nicejskim II, w: Wokót teologii ikony, red. B. Kochaniewicz, Studia Theologiae Fundamentalis, tom 2, Poznań 2011.

Ratzinger J., Duch liturgii, tł. E. Pieciul, Poznań 2002.

Schönborn Ch., Pokusa obrazoburcza, Communio 2/1990.

Sikorski D. A., Alkuin z Yorku na nowo odkrywany, w: Cognitioni Gestorum. Studia z dziejów średniowiecza dedykowane prof. Jerzemu Strzelczykowi, red. D. A. Sikorski, A. M. Wyrwa, Poznań-Warszawa 2006.

Starowieyski M., Sobory Kościoła Niepodzielonego, część 1 - Dzieje, Tarnów 1994.

Sulikowska-Gąska A., Spory o ikony na Rusi w XV i XVI w., Warszawa 2007.

Treppa Z., Tajemnica widzialności Boga. Szkice z teologii obrazu, Kraków 2015.

Włodarski Sz., Siedem soborów ekumenicznych, Warszawa 1969.

Wolny-Zmorzyński K., Fotograficzne gatunki dziennikarskie, Warszawa 2007.

\section{Streszczenie}

Nauka Soboru Nicejskiego II z 787 roku dotycząca kultu obrazów nigdy nie została w całości przyswojona przez Kościół Zachodni. Jednak spuścizna ta jest aktualna szczególnie dziś, w erze obrazu i komunikacji wizualnej, których wykorzystanie w ewangelizacji wydaje się być wymogiem naszych czasów. Dlatego też konieczne jest przeprowadzenie po raz wtóry głębszej refleksji nad miejscem i rolą świętego obrazu w Kościele, a także sięgnięcie do źródeł, wciąż aktualnej i nie do końca przyjętej, doktryny wypracowanej przez ten Sobór.

Słowa kluczowe: sobory powszechne, kult obrazów, teologia ikony, sztuka religijna, komunikacja wizualna.

THE TEACHING OF THE SECOND VATICAN COUNCIL ON THE IMAGES AND ITS RECEPTION IN THE WEST

Sum mary

The teaching of the Second Vatican Council of 787 on the cult of images has never been fully absorbed by the Western Church. This legacy is particularly relevant today, in the era of image and visual communication, whose use in evangelism seems to be a requirement of our time. It is therefore necessary to conduct a second deeper reflection on the place and role of the sacred image in the Church, and to reach out to the sources, still valid and not fully accepted, the doctrine elaborated by this Council.

Keywords: Common councils, Worship of images, theology of icons, religious art, visual communication. 